\title{
Growth, gas exchange and competitive ability of Sorghum halepense populations under different soil water availability
}

\author{
Eduardo S. Leguizamón ${ }^{1}$, Marcos E. Yanniccari ${ }^{2,3}$, Juan J. Guiamet ${ }^{2}$, and Horacio A. \\ Acciaresi $^{2}$ \\ ${ }^{1}$ Department of Crop Production Systems-Weeds, Facultad de Ciencias Agrarias, Universidad Nacional de \\ Rosario, S2125ZAA, Zavalla, Santa Fe, Argentina; and ${ }^{2}$ Instituto de Fisiología Vegetal (CIC-CONICET-UNLP), \\ Facultad de Ciencias Agrarias y Forestales, Universidad Nacional de La Plata, PO Box 31, (1900) La Plata, \\ Argentina. Received 14 October 2010, accepted 11 April 2011.
}

Leguizamón, E. S., Yanniccari, M. E., Guiamet, J. J. and Acciaresi, H. A. 2011. Growth, gas exchange and competitive ability of Sorghum halepense populations under different soil water availability. Can. J. Plant Sci. 91: 1011-1025. Different studies have determined that environmental variation is a key factor determining the outcome of competition within plant communities. Considering the importance of the resource water in non-irrigated lands of Argentina, the aim was to determine the effects of water deficit on relative growth rate (RGR), root length ratio (RLR), gas exchange and competitive ability of Sorghum halepense populations collected in humid and subhumid regions of the Pampa plains. Under semi-controlled conditions, we compared plants of seven $S$. halepense populations subjected to three different levels of soil water availability during 3 wk: Field capacity (FC), 75\% FC and drought (D). Moreover, total above-ground biomass of $S$. halepense and Zea mays plants growing together in competition was determined. It was found that those plants collected in humid or subhumid regions had greater RGR, gas exchange and RLR under FC and D, respectively. Zea mays achieved a higher competitive ability than $S$. halepense under FC, but plants collected in humid regions outcompeted the crop when grown at 75\% FC. Sorghum halepense plants collected in subhumid regions dominated under D. Root length ratio may have favored the maintenance of high levels of gas exchange and also high RGR, thus contributing to sustain a competitive hierarchy under soil water stress.

Key words: Relative growth rate, transpiration, photosynthesis, competition, weed biology

Leguizamón, E. S., Yanniccari, M. E., Guiamet, J. J. et Acciaresi, H. A. 2011. Croissance, échanges gazeux et compétitivité des peuplements de Sorghum halepense selon la quantité d'eau disponible dans le sol. Can. J. Plant Sci. 91: 1011-1025. Diverses études ont établi que la nature du milieu joue un rôle déterminant dans l'issue de la concurrence que se livrent les plantes. Sachant l'importance des réserves d'eau dans les terres de l'Argentine qui ne sont pas irriguées, les auteurs ont tenu à préciser l'incidence d'un stress hydrique sur le taux de croissance relatif (TCR), le ratio de la longueur des racines (RLR), les échanges gazeux et la compétitivité des peuplements de Sorghum halepense dans les régions humides et subhumides des plaines de la pampa. À cette fin, ils ont comparé les plants de sept peuplements de Sorghum halepense dans des conditions semi-contrôlées, aprés avoir soumis les végétaux à trois volumes d'eau disponible pendant trois semaines : la capacité du champ (CC), 75\% de la CC et la sécheresse. Ils ont également mesuré la biomasse aérienne totale des plants de Sorghum halepense et de Zea mays cultivés ensemble, et qui se livraient concurrence. Les auteurs ont constaté que les plants recueillis dans les régions humides ou subhumides se caractérisent par un TCR, des échanges gazeux et un RLR plus élevés à la CC et pendant la sécheresse, respectivement. Zea mays s'avére plus compétitif que Sorghum halepense à la CC, mais les plants des régions humides surpassent la culture à $75 \%$ de la CC. Les plants de Sorghum halepense des régions subhumides dominent durant la sécheresse. Le RLR pourrait favoriser le maintien d'un niveau élevé d'échanges gazeux et un TCR supérieur, ce qui concourrait à préserver la hiérarchie concurrentielle quand l'eau vient à manquer dans le sol.

Mots clés: Taux de croissance relatif, transpiration, photosynthèse, compétition, biologie des mauvaises herbes

Plant interactions may involve positive (i.e., facilitation) and neutral or negative (i.e., competition) effects on the performance of plants sharing limited resources (Lindquist, 2001). Booth et al. (2003) determined that a better competitor will suffer, in turn, less competition from its neighbors. Thus, enhanced competitive ability

\footnotetext{
${ }^{3}$ Corresponding author (e-mail: marcosyanniccari@) conicet.gov.ar).
}

may be explained by an increased resource capture or, vice versa, by an increased tolerance to deficits of resources (Goldberg and Landa 1990). Under this view, competitive ability consists of: (i) suppression capacity,

\footnotetext{
Abbreviations: $\boldsymbol{A}$, photosynthetic rate; $\mathbf{D}$, drought; DAE, days after emergence; $\boldsymbol{E}$, transpiration rate; $\mathbf{F C}$, field capacity; $\boldsymbol{G}_{\mathbf{s}}$, Stomatal conductance; RGR, relative growth rate; RLR, root length ratio; RMF, root mass fraction; RYT, relative yield total; SRL, specific root length
} 
(ii) tolerance to competition or competitive response (Jannink et al. 2001).

Different studies have determined that environmental variation is a key factor determining the outcome of competition within mixed plant communities (e.g., McDonald et al. 2004). Thus, a competitive hierarchy may be established. The competitive hierarchy consists of ranking the species according to its growth and biomass allocation capacity under different environments (Novoplansky and Goldberg 2001). Competitive hierarchies in different environments are the basis for the differences in the community structure models proposed by Novoplansky and Goldberg (2001). Different experiments have demonstrated the limitations of searching for a unique, solely competitive hierarchy ranking among different species in variable environments (Novoplansky and Goldberg, 2001). The ranking seems to be highly dependent on the variations in the environmental conditions where the experiments were carried out (Holt and Orcut, 1991). McDonald et al. (2004) determined that environmental variability has a very important influence in the course of the competitive processes in different crop-weed associations, thus influencing the pattern of yield reductions. Thus, the competitive differences between species will be determined by the variation in growth and reproductive response to environmental conditions and agroecosystem management $(\mathrm{McD}$ onald et al. 2004).

There is very little information available on the impact of water availability on competitive interactions (Novoplansky and Goldberg, 2001). Wiese and Vandiver (1970), studying competition for water, determined that weeds producing higher above-ground biomass under field capacity had a very poor performance when the water availability in the soil decreased, as compared with species adapted to constant low-water availability. Differences in the competitive ability of species may be assessed by measuring the growth rates and the reproductive outputs in variable environmental conditions. Weeds tend to adjust faster than crops to changing resource availability and management practices (Booth et al. 2003).

Bradshaw (1965) determined two plastic responses to environmental change. One is related to the replacement of existing tissues with new ones (morphological response). The second is represented by reversible changes at a sub-cellular level (physiological response), a faster and lower cost response as compared with a morphological response, but with a low probability to influence the spatial adjustments, a characteristic of success when environmental changes occur (Grime and Mackey 2002). These authors claim that the plasticity mechanisms cannot develop independently of the habitat, and they cannot be seen isolated from other selection mechanisms simultaneously operating on other plant traits. Grime and Mackey (2002), hypothesized that both plasticity forms will then be closely correlated with a series of traits, which will likely become predominant in different environments. In this way, morphological plasticity will prevail in species growing high resource availability environments. The high resource consumption will generate aerial and subterranean spatial mosaics of resource availability, which will lead to a continued replacement of leaves and roots located in the areas where resources have been completely depleted (Grime and Mackey 2002). According to these authors, this strategy is not feasible for species with slow growth rates, adapted to unproductive environments. Grime and Mackey (2002) have determined that those species having high relative growth rate (RGR) and also growing in high resource availability environments depend to a greater extent on morphological plasticity than species with low RGR, surviving in poor-resources environments. These authors predict that physiological plasticity is an important homeostatic mechanism that will help to maintain tissue viability and cell functionality in such environments.

As far as we are aware, there are no studies that incorporate an analysis of phenotypic plasticity despite the importance of this strategy on competitive processes. In this paper, we address the role of both types of plasticity in resource-capture (Sultan 2000) and also their consequences in the competitive process (Grime and Mackey 2002).

Experimental work on Sorghum halepense (L.) Pers. (Johnson grass) has largely focused on the behavior of different ecotypes under different environmental and management conditions, but mainly on the effects of herbicides (Burt 1974; McWhorter and Jordan 1976).

Crops have been subjected to a very intense selection process under uniform conditions, which has resulted in less morphological and physiological plasticity in response to changes in the environment (Holt 1988). This scenario will likely promote specific responses instead of phenotypic plasticity (Semchenko and Zobel 2005). According to this proposal, when available resources vary, responses of the cultivated plant (crop) and the weed may also vary. This, in turn, may lead to modifications in the output of the competitive process (Acciaresi and Guiamet 2010).

Considering the key importance of water resource in the non-irrigated, extensive crop production systems of the Pampa plains of Argentina, experiments were established in order to investigate the morphophysiological responses to water deficit in different populations of Sorghum halepense. This alien species, introduced to Argentina a century ago as forage crop (Leguizamón 2003), still invades a wide variety of agro-ecosystems, despite the tremendous efforts to control it (Leguizamón 2003). It is presumed that although populations may still be under an on-going adaptation process in each region, they may already have incorporated differential mechanisms, according to the different environments where they have been growing. Therefore, we studied the plasticity of plants of different populations of $S$. halepense when growing in monoculture, and we also determined the 
outcome of the interspecific competition, when growing with $Z$. mays L. under a range of soil water availability conditions. Experiments were designed to test the following hypotheses: (i) Morphological and physiological response to water supply treatment will vary among $S$. halepense populations depending upon the location where each population became naturalized. (ii) The competitive tolerance of a $S$. halepense population will vary among soil water treatments. (iii) Since the behavior of weed and crop species may be affected by soil water availability, the aggressivity of $S$. halepense will vary among soil water treatments.

\section{MATERIALS AND METHODS}

Two experiments were carried out to test the hypotheses. In a first assay, the morphological and physiological responses of $S$. halepense biotypes, under different water availabilities, were evaluated. The competitive ability of $S$. halepense was studied in a second experiment.

\section{Experimental Conditions}

In April 1999, a field survey was conducted in a region of the Pampa plains, to search for adapted and presumably naturalized populations of $S$. halepense growing in recently harvested soybean or corn fields located in high yield potential soils, as selected by expert agronomists in each area. Rhizomes were collected from seven pre-selected areas ranging from 400 and $650 \mathrm{~km}$ (Table 1). Rhizomes were washed and stored in plastic bags at $4.0^{\circ} \mathrm{C}$ until the initiation of the experiments. Experiments were carried out outdoors, in the Plant Physiology Institute (INFIVE-CONICET) and Cereal Crops Department, Faculty of Agronomy and Forest Sciences, National University of La Plata (Lat. $34^{\circ} \mathrm{S}$, Long. $58^{\circ} \mathrm{W}$ ), from October to January, 2001 to 2004. One plant of the weed or three weed + three $Z$. mays plants were grown in plastic pots, $50 \mathrm{dm}^{3}$ or $84 \mathrm{dm}^{3}$ (exps. 1 and 2, respectively), filled with a mixture of soil, peat and sand (7:1:2 vol/vol), fertilized with urea and tricalcium superphosphate $\left(10\right.$ and $9 \mathrm{~g} \mathrm{~m}^{-2}$, respectively). In both experiments, $S$. halepense plants were grown from rhizomes stored at low temperature $\left(4.0^{\circ} \mathrm{C}\right)$. These were cut into segments bearing two nodes $(4$ to $7 \mathrm{~g}$ segment ${ }^{-1}$ ), gently washed and then soaked for $15 \mathrm{~min}$ in a benomyl solution $\left(0.35 \mathrm{~g} \mathrm{~L}^{-1}\right)$. They were then placed in plastic trays filled with washed sand in a growth chamber at $28^{\circ} \mathrm{C}$ until sprouting was evident.
In each experiment, one or three rhizome segments were transplanted into the center of each container at a $3 \mathrm{~cm}$ depth. A layer $(1 \mathrm{~cm})$ of polystyrene beads was placed above the soil to prevent evaporation. Pots were watered daily to maintain a $-0.03 \mathrm{MPa}$ soil water level (approximately field capacity) during the initial $3 \mathrm{wk}$ after weed emergence. Occasional watering by rainfalls that might occur in the site was avoided by temporarily covering the pots with polyethylene sheets. Each group of experiments was replicated two times.

\section{Experiment 1. Growth and Gas Exchange of Sorghum halepense Populations}

Treatments, Experimental Design

Treatments tested were: Origin of the population (seven populations, Table 1) and soil water availability as follows: (a) soil water maintained at $-0.03 \mathrm{MPa}(\mathrm{FC})$, (b) soil water maintained at $-0.04 \mathrm{MPa}$ (approximately $75 \%$ FC, moisture content: 23.5 to $25 \% \mathrm{wt} / \mathrm{wt}$ ) and (c) drought ( $\mathrm{D}$, watering withheld). These treatments lasted from day 21 to day 45 after weed emergence (days after emergence, DAE). Each complete randomized block, with six replicates, had seven populations $\times$ three soil water conditions.

\section{Variables and Measurements}

The soil water potential $\left(\psi_{\mathrm{s}}, \mathrm{MPa}\right)$ was determined only in FC and D treatment pots, starting $4 \mathrm{~d}$ after the drought period was initiated and every third subsequent day, using porous capsules (Thermolink, Decagon Devices, Pullman, WA) and a soil moisture probe (Hydrosense 300, Campbell Scientific, Logan, UT).

Relative growth rate $\left(\mathrm{mg} \mathrm{g}^{-1} \mathrm{~d}^{-1}\right)$ was determined using the differences in plants dry weights between two consecutive harvests (Poorter 1989). In every harvest, plants were separated from the soil mixture by washing and dispersing the soil aggregates with a 5\% sodium hexametaphosphate solution (Malone 1967). Each plant was then separated into pieces and the material classified into above- and below-ground mass, this latter one also splitted into rhizomes and roots. All plant material was dried in a circulating air oven at $65^{\circ} \mathrm{C}$ to a constant weight.

The ratios: (a) root length (RLR, $\mathrm{m}$ root $\mathrm{g}^{-1}$ plant), (b) root mass fraction (RMF, g root $\mathrm{g}^{-1}$ plant), and (c) specific root length (SRL, $\mathrm{m}$ root $\mathrm{g}^{-1}$ root), were

\begin{tabular}{|c|c|c|c|c|c|c|}
\hline Location & Code & Province & Field coordinates & Climate & Average rainfall 1970-2000 $\left(\mathrm{mm} \mathrm{yr}^{-1}\right)$ & Average air temperature $\left({ }^{\circ} \mathrm{C}\right)$ \\
\hline Santa Rosa & Ro & La Pampa & $36^{\circ} 37^{\prime} \mathrm{S} 64^{\circ} 17^{\prime} \mathrm{W}$ & Subhumid & 638 & 15.0 \\
\hline General Pico & $\mathrm{Pi}$ & La Pampa & $35^{\circ} 40^{\prime} \mathrm{S} 63^{\circ} 44^{\prime} \mathrm{W}$ & Subhumid & 723 & 16.1 \\
\hline Rio Cuarto & R.IV & Córdoba & $33^{\circ} 08^{\prime} \mathrm{S} 64^{\circ} 21^{\prime} \mathrm{W}$ & Subhumid & 815 & 16.7 \\
\hline Laboulaye & $\mathrm{Lb}$ & Córdoba & $34^{\circ} 07^{\prime} \mathrm{S} 63^{\circ} 23^{\prime} \mathrm{W}$ & Subhumid & 837 & 16.2 \\
\hline Rojas & $\mathrm{Rj}$ & Buenos Aires & $34^{\circ} 12^{\prime} \mathrm{S} 60^{\circ} 44^{\prime} \mathrm{W}$ & Humid & 990 & 16.4 \\
\hline Paraná & $\operatorname{Pr}$ & Entre Ríos & $31^{\circ} 44^{\prime} \mathrm{S} 60^{\circ} 32^{\prime} \mathrm{W}$ & Humid & 1016 & 18.0 \\
\hline La Plata & LP & Buenos Aires & $34^{\circ} 55^{\prime} \mathrm{S} 57^{\circ} 57^{\prime} \mathrm{W}$ & Humid & 1023 & 16.3 \\
\hline
\end{tabular}


only calculated for $S$. halepense populations from two contrasting-regions [La Plata (LP) and Santa Rosa (Ro)], at 33 and $45 \mathrm{~d}$ after weed emergence.

Gas exchange measurements, included: (a) Photosynthetic rate, $A\left(\mu \mathrm{mol} \mathrm{CO} \mathrm{Cm}^{-2} \mathrm{~s}^{-1}\right)$ measured in every third day from 21 to 42 DAE with a portable photosynthesis system (IRGA, LI-6200, Li-Cor, NE), between 1100 and 1400 on sunny days, and (b) Stomatal conductance $\left(G_{\mathrm{s}}\right)$ and transpiration rate $(E)$ (mmol $\mathrm{H}_{2} \mathrm{O} \mathrm{m}^{-2} \mathrm{~s}^{-1}$ ). Both were determined on the abaxial face of last fully expanded leaf exposed to direct solar radiation by using a LI-1600 Li-Cor, NE steady state porometer, under the same conditions as for photosynthesis.

\section{Experiment 2. Competitive ability of Sorghum halepense Populations and Zea mays}

Experimental procedures were similar to those of exp. 1 . Monocultures of $S$. halepense and $Z$. mays were established by planting three pre-sprouted rhizomes or six pregerminated seeds of a single Z. mays hybrid cv. AX 840 in each pot, and then thinned to three true-established plants. In the crop-weed association, three Z. mays + three $S$. halepense plants were grown together in each pot. All pots werey watered daily following the same procedures, and water availability treatments as in exp. 1 . The period for testing the effects of soil water availability (21-45 DAE) was selected because it matches to the "critical period" for weed competition in this weed-crop association (Ghosheh et al. 1996). As in exp. 1, after the 45th day, all pots were watered daily until the end of the experiment (crop phenological stage $\mathrm{R}_{1}$ ).

\section{Treatments, Experimental Design}

A single density additive design was used. Three treatments were set: (a) Weed monoculture, (b) Crop monoculture, (c) Crop + Weed association. Sub-treatments were: (a) pots at FC, (b) pots at 75\% FC and (c) pots under dry condition (D). A complete randomized block design with three replicates was used.

\section{Variables and Measurements}

Resource complementarity, the extent to which the crop and the weed shared common limiting resources, was measured by relative yield total (RYT). Competitive ability was measured by "aggressivity", which takes into account the effect of competition on both the crop and the weed (Satorre and Snaydon 1992).

Plant biomass was determined as in exp.1. The RYT (de Witt and Van der Bergh, 1965), Eq. 1, and the aggressivity index (Satorre and Snaydon 1992), Eq. 2, were calculated as follows:

$$
\begin{aligned}
& \mathrm{RYT}=\left(B_{\mathrm{ij}} / B_{\mathrm{ii}}\right)+\left(B_{\mathrm{ji}} / B_{\mathrm{jj}}\right) \\
& \left.\mathrm{AGR}=\left(B_{\mathrm{ij}} / B_{\mathrm{ii}}\right)-\left(B_{\mathrm{ji}} / B_{\mathrm{jj}}\right)\right) \times \mathrm{RYT}^{-1}
\end{aligned}
$$

Where $B_{\mathrm{ij}}$ and $B_{\mathrm{ji}}$ are biomass per plant of species $i$ (Z. mays) and $j$ (S. halepense) when growing in mixture and $B_{\mathrm{ii}}$ and $B_{\mathrm{jj}}$ are the biomass per plant when growing in monocultures. The relative biomass is also shown for each species to calculate competition tolerance and the ability to suppress the competitor. Since there were three plants of each species in each pot, there were no proportion adjustments: positive values will therefore indicate higher $Z$. mays aggressivity and negative values will then indicate higher $S$. halepense aggressivity.

\section{Statistical Analysis}

Variables of growth and gas exchange of $S$. halepense populations were evaluated by multi-factorial ANOVA. Means were compared using $t$-tests with the relevant degrees of freedom. For those variables sequentially measured along the period 21-42 d after emergence $\left(\psi_{\mathrm{s}}, \mathrm{RGR}, A, G_{\mathrm{s}}\right.$ and $\left.E\right)$, a second-order interaction between the treatments Origin $\times$ Available water at each harvest time was calculated (Sultan 2000). All comparisons were set at $P<0.05$.

An ANOVA was made on RYT and AGR values for each treatment. Based on a Barttlet's test for variance homogeneity, data were transformed to square root, then back-transformed for graphical purposes. Standard error (SE) was used to analyze treatment effects.

For these tests, statistical package used was Statgraphic ${ }^{\circledR}$ plus 5.1. (Statistical Graphics Corp).

\section{RESULTS \\ Growth and Gas Exchange in Sorghum halepense Populations}

\section{Soil Water Potential $\left(\psi_{s}\right)$}

There were no differences, or second- or third-order interactions by year in the data $(P=0,654)$. Results are thus presented with the 2 -yr data averaged. Multivariate analysis of $\psi_{\mathrm{s}}$ showed a significant effect $(P<0.05)$ for weed population and soil water level. A second- order interaction was also shown $(P<0.05$ and $P<0.01)$ (Table 2). Soil water potential $\left(\psi_{\mathrm{s}}\right)$ changed through time, but it also showed a different pattern in each population (Fig. 1). Under D, $\psi_{\mathrm{s}}$ consistently dropped during the experiment, with the Ro population reaching lower $\psi_{\mathrm{s}}$ values than LP from 30 DAE until the end of the experiment (Fig. 1).

\section{Relative Growth Rate}

Multivariate analysis showed significant effects for origin and soil water level along the time-course of the experiment $(P<0.05)$ (Table 3$)$. Second-order interactions were also shown $(P<0.05$ and $P<0.01)$ (Table 3$)$. Relative growth rate variations in time (Fig. 2) depended on the $S$. halepense population. Under FC, plants of humid regions [Paraná (Pr); Rojas $(\mathrm{Rj})$ and La Plata (LP)] had significantly higher RGR compared to those of subhumid regions [Santa Rosa (Ro), General Pico (Pi) and Río Cuarto (R.IV)], Fig. 2a. Plants of the Laboulaye (Lb) population from a subhumid region showed intermediate behavior, which did not differ significantly from 


\begin{tabular}{lrrrr}
\hline $\begin{array}{l}\text { Table 2. Effects of time and Sorghum halepense population on soil water } \\
\text { availability }\end{array}$ & $\mathrm{Df}^{\mathrm{z}}$ & $\mathrm{MRS}^{\mathrm{Z}}$ & $F$ & $P$ \\
\hline Source of variation & 5 & 0.785 & 4.51 & 0.037 \\
\hline Time & 1 & 1.774 & 10.15 & 0.019 \\
Sorghum halepense population & 1 & 7.121 & 24.18 & 0.014 \\
Soil water availability & 5 & 0.107 & 4.39 & 0.022 \\
Time $\times$ population & 5 & 3.144 & 1.12 & 0.039 \\
Time $\times$ soil water availability & 1 & 1.981 & 6.14 & 0.012 \\
Population $\times$ soil water availability & & & &
\end{tabular}

${ }^{\mathbf{z}}$ Df, degrees of freedom; MRS, mean residuals square. ANOVA Model $r^{2}=0.811$

populations from the humid or subhumid regions. Relative growth rate did not vary along the time-course of the experiment in any population. Under $\mathrm{FC}$ and $75 \%$ FC, the RGR values of populations from the subhumid regions did not differ significantly (Fig. 2b). However, RGR significantly decreased over time: during the first week, plants of the Pr; Rj, LP and Lb populations had significantly higher RGR than those of R.IV, Ro and Pi (Fig. 2b), although by day 10 only plants of PR population maintained high RGR values compared with those of the subhumid region. The RGR of the populations did not differ beyond day 10 (Fig. 2b). Under the D treatment, plants of the subhumid region (R.IV, Ro and Pi) showed a significant reduction in RGR, but only by the end of the experiment (Fig. 2c). The Lb population again showed similar RGR as populations of the humid regions (Fig. 2c). Reduction in RGR of the plants of the humid-region ( $\mathrm{PR}, \mathrm{Rj}$ and $\mathrm{LP}$ ) was highly significant as compared with the RGR value they exhibited before starting the water stress period (Fig. 2c). Plants of $\mathrm{Pr}$ and

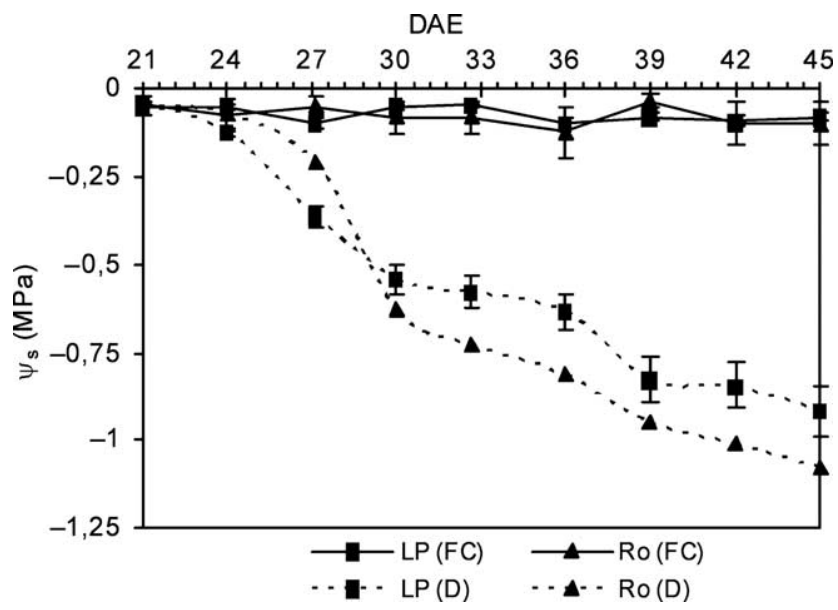

Fig. 1. Time-course (days after emergence, DAE) of soil water potential $\left(\psi_{\mathrm{s}}, \mathrm{MPa}\right)$ of Sorghum halepense populations from subhumid (Santa Rosa, Ro) and humid (LaPlata, LP) regions, grown at two level of water availability [field capacity, FC, and drought (watering withheld) D]. Values were averaged over two growing seasons. Vertical bars indicate standard error (SE) $(n=6)$.
Table 3. Effects of time, Sorghum halepense population and soil water availability on the RGR $\left(\mathrm{mg} \mathrm{g} \mathrm{d}^{-1}\right)$ of Sorghum halepense

\begin{tabular}{lrrrc}
\hline Source of variation & $\mathrm{Df}^{\mathbf{Z}}$ & $\mathrm{MRS}^{\mathbf{z}}$ & \multicolumn{1}{c}{$F$} & $P$ \\
\hline Time & 5 & 101.024 & 8.77 & 0.018 \\
Sorghum halepense population & 6 & 64.022 & 6.78 & 0.030 \\
Soil water availability & 2 & 180.421 & 21.41 & 0.011 \\
Time $\times$ population & 30 & 63.812 & 4.99 & 0.048 \\
Time $\times$ soil water availability & 10 & 61.748 & 5.77 & 0.039 \\
Population $\times$ soil water availability & 12 & 55.476 & 5.01 & 0.041 \\
\hline
\end{tabular}

${ }^{\mathrm{z}} \mathrm{Df}$, degrees of freedom; MRS, mean residual squares. ANOVA Model $r^{2}=0.775$

LP showed an early decrease in RGR as compared with that of the subhumid region, and differences continued till the end of the experiment (Fig. 2c).

\section{Root Length Ratio, Root Mass Fraction, Specific Root Length}

Root parameters were determined at 33 and $45 \mathrm{~d}$ after emergence only in plants of the weed populations LP and Ro (the most contrasting regions). Root length ratio significantly increased at $75 \% \mathrm{FC}$, and under D conditions, compared with FC (Fig. 3a). Under FC, plants of LP showed a significantly lower RLR than those of Ro at 33 and 45 DAE. At $75 \%$ FC there were no significant differences among populations, but plants from Ro had higher RLR values when grown under D (Fig. 3a). In all the soil water conditions, plants of the Ro population had significantly higher RMF than LP plants, at both sampling dates (Fig. 3b).

Specific root lengths of LP plants were significantly higher than those of Ro plants under FC and 75\% FC, without any significant change between 33 and 45 DAE (Fig. 3c). In contrast, Ro plants had higher SRL than LP plants under D conditions, and this difference was larger as the experiment approached its end, indicating an increase in the number of small- thinned roots.

\section{Gas Exchange}

\section{Photosynthetic Rate (A)}

Photosynthetic rate differed significantly depending on time, origin of the population and soil water status. Second-order interactions were also present (Table 4). Thus, this analysis focused on each water treatment separately (Fig. 4). Photosynthetic rates followed the same trends as RGR, i.e., the photosynthetic rate was significantly related to the origin of each population. Under FC, $A$ was significantly higher for plants of the populations collected in the humid region $(\mathrm{Pr} ; \mathrm{Rj}$ and LP), compared with that of subhumid region populations (R.IV, Ro and $\mathrm{Pi}$ ), although plants of $\mathrm{Lb}$ population exhibited intermediate values (Fig. 4a). At $75 \%$ FC, plants of populations from the humid region maintained higher $A$, although only for $10 \mathrm{~d}$ after initiation of the different soil watering regimes (Fig. 4b). Thereafter, $A$ had similar values in all populations. 

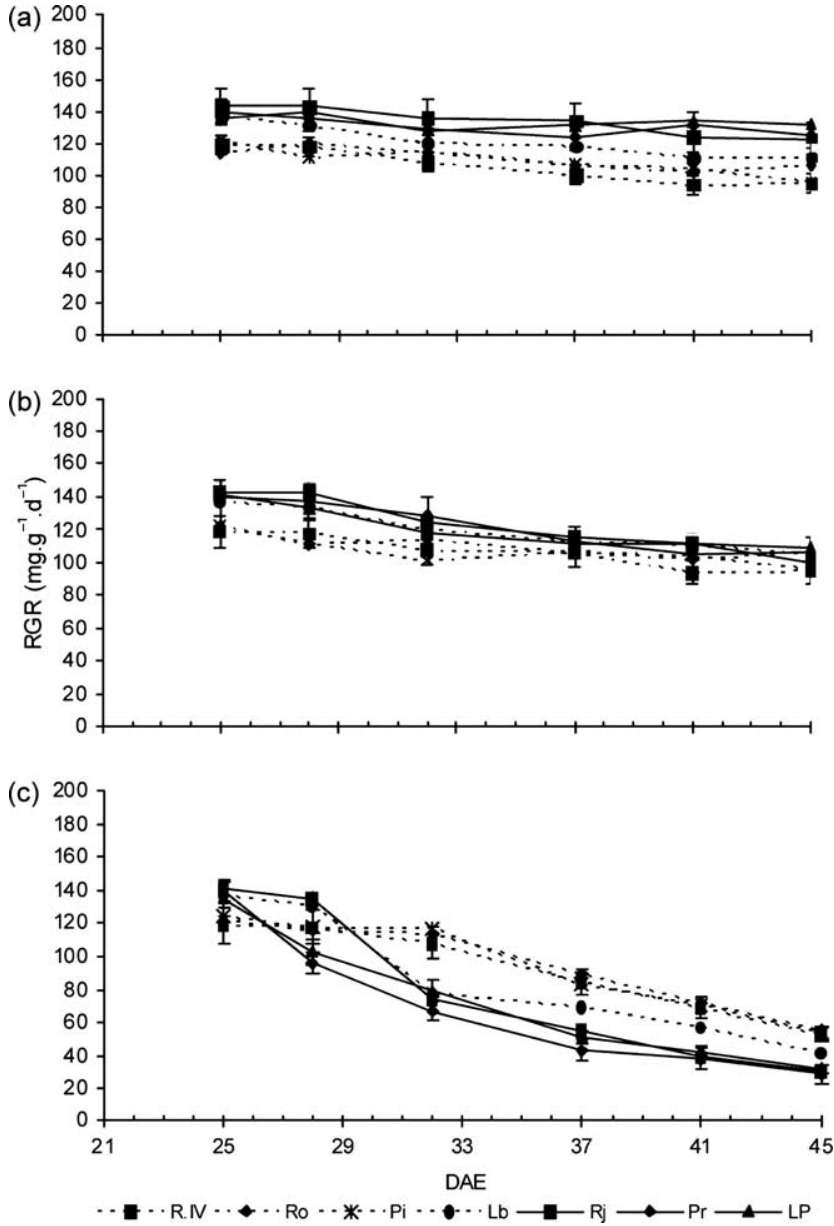

Fig. 2. Time course (days after emergence, DAE) of relative growth rate [RGR $\left(\mathrm{mg} \mathrm{g}^{-1} \mathrm{~d}^{-1}\right)$ ] for Sorghum halepense populations from subhumid (Río IV (R.IV), Santa Rosa (Ro), Pico (Pi) and Laboulaye (Lb) and humid (Rojas (Rj), Paraná $(\mathrm{Pr})$ and La Plata (LP)) regions, grown at three level of water availability: (a) field capacity (FC), (b) $75 \%$ FC and (c) drought (watering withheld). Values were averaged over two growing seasons. Vertical bars indicate standard error (SE) $(n=6)$.

Under D, high photosynthetic rates of the populations collected in the humid region were sustained only for $4 \mathrm{~d}$. By day 7, all populations had low photosynthetic rates. From this date onwards, the $A$ values of the populations R.IV, Ro and Pi were higher than those recorded for populations collected in humid regions (Fig. 4c).

\section{Stomatal Conductance to Water Vapor $\left(G_{\mathrm{s}}\right)$}

As for $A$, time, origin and soil water availability had a significant influence on stomatal conductance. Secondorder interactions were also significant $(P<0.05)$ (Table 5). As determined for RGR and $A$, stomatal conductance of the plants of the seven populations was related to their geographical origin. Under FC, stomatal conductance of $\mathrm{Pr}, \mathrm{Rj}$ and LP plants was significantly higher than that of R.IV, Ro and Pi (Fig. 5a). At 75\% FC, and up to the 25th DAE, plants of populations from the humid region ( $\mathrm{Pr}, \mathrm{Rj}$ and $\mathrm{LP}$ ) and $\mathrm{Lb}$ exhibited higher conductance values. Under $75 \%$ FC, on the 25th DAE, populations Rj and Ro-Pi differed significantly (Fig. 5b). Under D, plants of all populations showed not only a significant reduction in their stomatal conductance, but it was also evident very soon after establishment of water deficit (Fig. 5c). Rj, Pr and LP showed lower $G_{\mathrm{s}}$ than R.IV, Ro, $\mathrm{Pi}$, and $\mathrm{Lb}$ throughout the experimental period (i.e., from 31 to 46 DAE).

\section{Transpiration Rate $(E)$}

Transpiration rate was statistically different during the experiment (Table 6). Significant variations were determined in relation to soil water status. Second-order interactions were also present (Table 6). Under FC, the transpiration rates of the populations collected in the humid regions ( $\mathrm{Pr}, \mathrm{Rj}$ and $\mathrm{LP}$ ) were higher than those of the populations in subhumid regions (R.IV, Ro and Pi) (Fig. 6a). Plants of the Lb population had intermediate values after the second week of treatment. At $75 \%$ FC and also under $\mathrm{D}$, the behavior of the populations was similar to that observed for other parameters of gas exchange.

\section{Competitive ability of Sorghum halepense populations and Zea mays}

There were no differences, or any second- or third-order statistical interaction by year in the data of the two different years $(P=0,654)$. Analysis is thus presented with the 2-yr data averaged.

\section{Resource Complementarity}

A RYT value not significantly different from $1(P<0.05)$ indicates full resource competition, whereas a RYT value significantly higher than 1 would indicate some degree of competition. Under FC, RYT was $>1$ in all corn/weed associations, indicating that an incomplete competition between both components of the mixture was established (Table 7). Under 75\% FC the RYT showed the absence of complementarity, indicating a full competitive process. Competition increased as water soil availability decreased (D) (Table 7).

\section{Competitive Ability}

Competitive ability was determined by calculating the AGR, and its components (the tolerance to competition and suppression ability of the weed or, in turn, the competitive tolerance of $Z$. mays). Under FC, plants of $S$. halepense populations collected in humid regions had a greater tolerance to competition than populations from subhumid areas, without differences among the populations of a given region (Fig. 7a). Zea mays tolerance to competition (or the suppressive capacity of weed populations) was higher for populations of the subhumid regions (Fig. 7b). However, there were no 

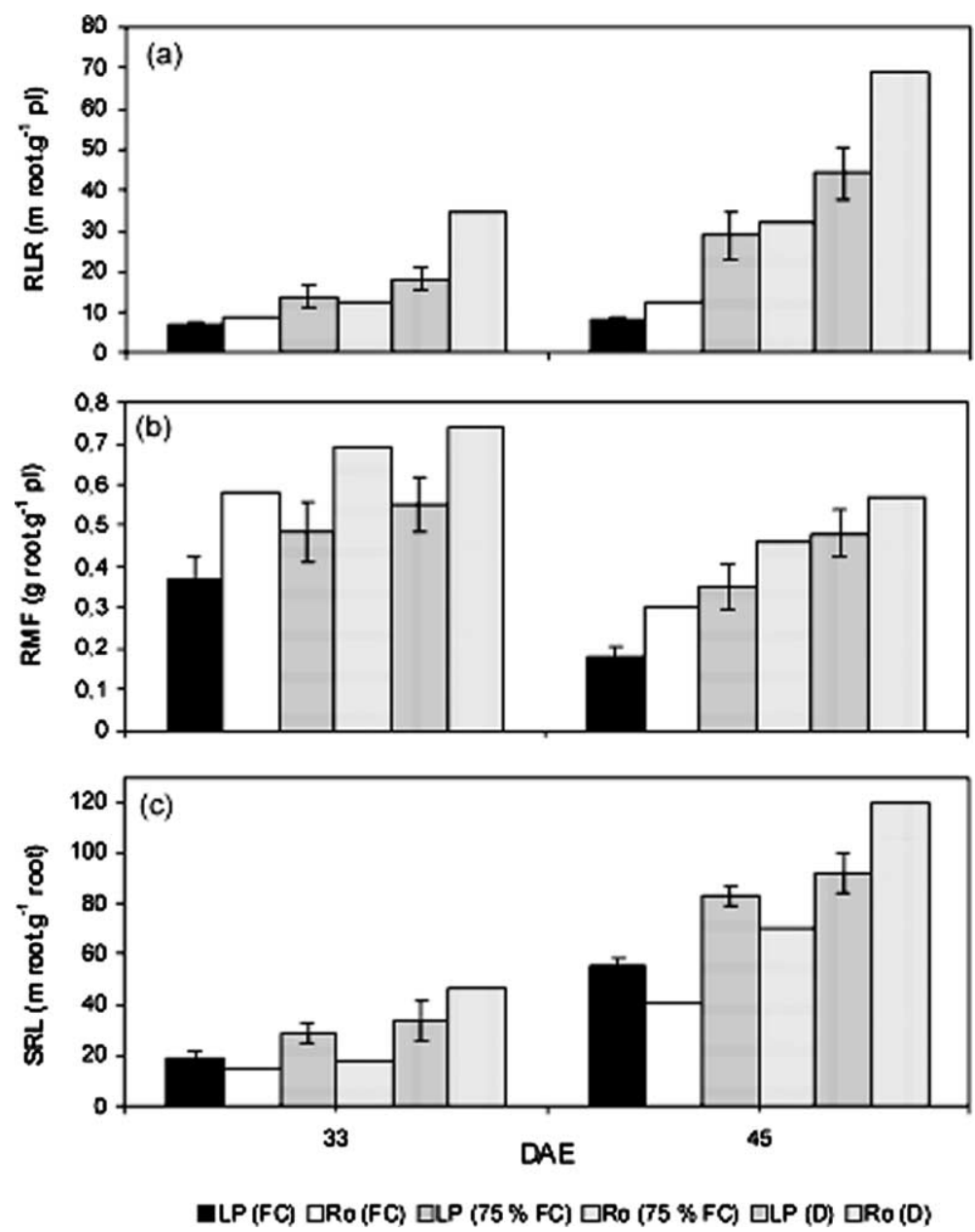

Fig. 3. (a) Root length ratio (RLR, $m$ root $\mathrm{g}^{-1}$ plant), (b) root mass fraction (RMF, $g$ root $\mathrm{g}^{-1}$ plant) and (c) specific root length (SRL, $\mathrm{m}_{\text {root }} \mathrm{g}^{-1}$ root) of two Sorghum halepense plant populations: La Plata (LP) and Santa Rosa (Ro) from humid and subhumid regions respectively, at 33 and $45 \mathrm{~d}$ after emergence (DAE) grown at three level of water availability: field capacity (FC), 75\% FC and drought (watering withheld, D). Values were averaged over two growing seasons. Vertical bars indicate standard error (SE) $(n=6)$.

differences when water availability decreased to $75 \%$ FC (Fig. 7c), although tolerance of $S$. halepense to competition was higher than the tolerance to competition of Z. mays (Fig. 7d). In this case, suppression ability of the populations Rj, PR and LP was significantly higher than that of populations from the subhumid regions (Fig. 7d). Under D conditions, the tolerance to competition of the weed was significant higher than that of the crop. R.IV, Ro and Pi showed greater tolerance to crop competition than plants of populations $\mathrm{Lb}, \mathrm{PR}, \mathrm{Rj}$ and $\mathrm{LP}$ (Fig. 7e). In terms of tolerance to competition of the crop (or suppressive capacity of the weed), the populations R.IV, Ro and Pi had greater suppression capacity than $\mathrm{Lb}, \mathrm{PR}, \mathrm{Rj}$ and LP (Fig. 7f).

Under FC, Z. mays had higher aggressivity than any of the seven $S$. halepense populations, although this attribute was more evident in those collected in the subhumid regions (R.IV, Ro and Pi, Fig. 8a). Conversely, under $75 \% \mathrm{FC}$, populations of the weed had higher aggressivity than the crop. Among weed populations, the highest aggressivity was observed in those collected in the humid regions ( $\mathrm{Pr}, \mathrm{Rj}$ and LP compared with R.IV, Ro, Pi and Lb). Aggressivity under the severe water deficit condition (D) was higher for any weed population compared with the crop, but the highest aggressivity was in the populations collected in the subhumid regions (Fig. 8c).

\section{DISCUSSION}

\section{Growth and Gas Exchange in Sorghum halepense Populations}

Soil water availability modified above- and belowground growth of $S$. halepense populations. Populations collected in humid regions had higher RGR when grown at FC. In searching for same responses, Wiese and 
Table 4. Effects of time, Sorghum halepense type of population and soil water availability on photosynthetic rate $\left(A, \mu \mathrm{mol} \mathrm{CO}_{2} \mathrm{~m}^{-2} \mathrm{~s}^{-1}\right)$ of Sorghum halepense

\begin{tabular}{lrrrc}
\hline Source of variation & $\mathrm{Df}^{\mathbf{Z}}$ & $\mathrm{MRS}^{\mathbf{z}}$ & \multicolumn{1}{c}{$F$} & $P$ \\
\hline Time & 5 & 77.045 & 6.74 & 0.022 \\
Sorghum halepense population & 6 & 54.574 & 5.95 & 0.028 \\
Soil water availability & 2 & 132.244 & 21.28 & 0.000 \\
Time $\times$ population & 30 & 77.518 & 4.56 & 0.043 \\
Time $\times$ soil water availability & 10 & 67.842 & 5.44 & 0.036 \\
Population $\times$ soil water availability & 12 & 71.610 & 6.58 & 0.025 \\
\hline
\end{tabular}

${ }^{\mathbf{z}}$ Df, degrees of freedom; MRS, mean residuals square. ANOVA Model $r^{2}=0.787$.

(a)
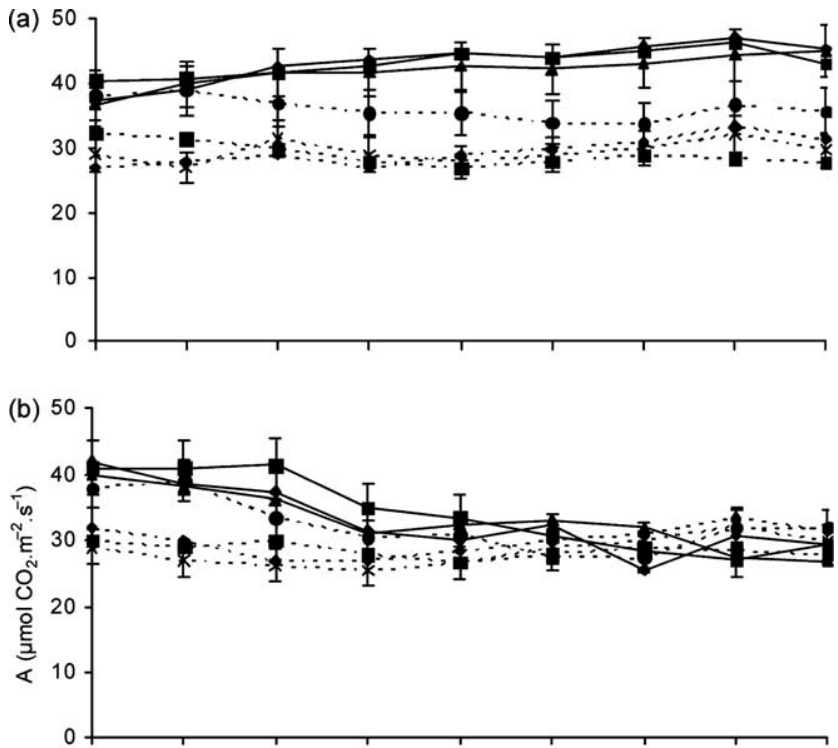

(c)

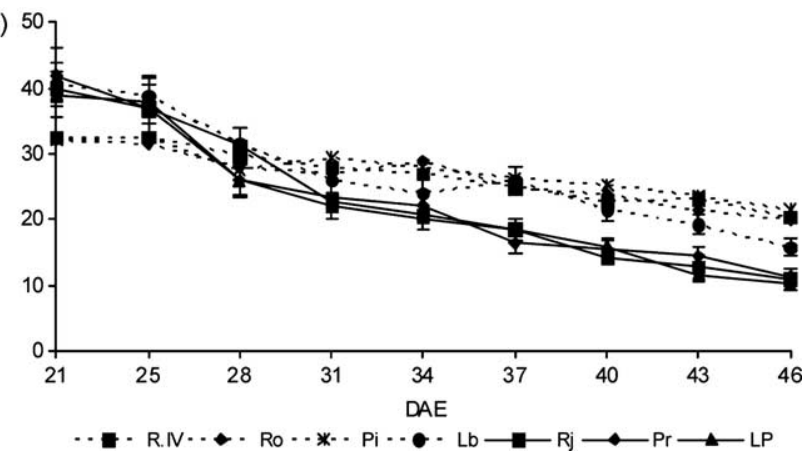

Fig. 4. Time course (days after emergence, DAE) of photosynthesis rate $\left(A, \mu \mathrm{mol} \mathrm{CO}_{2} \mathrm{~m}^{-2} \mathrm{~s}^{-1}\right)$ for seven Sorghum halepense populations: Río IV (R.IV), Santa Rosa (Ro), Pico (Pi) and Laboulaye (Lb) from subhumid region and Rojas ( $\mathrm{Rj}$ ), Paraná $(\mathrm{Pr})$ and La Plata (LP) from humid region, grown at three level of water availability: (a) field capacity (FC), (b) $75 \%$ FC and (c) drought (watering withheld). Values were averaged over two growing seasons. Vertical bars indicate standard error (SE) $(n=6)$.
Vandiver (1970) found that growth of weed populations adapted to high water supply significantly decreased under low water supply, whereas populations adapted to more water-restricted environments have similar biomass productions in both environments. In our experiments, as soil water availability decreased, populations from subhumid regions exhibited a higher RGR than those from humid regions. Differences in RGR between populations and water treatments were related to the dynamics of the root system; RLR varied according to the population and environment. Under FC both types of population (characteristic of humid and subhumid regions) had different RLR, RMF and SRL values. Plants from the humid region had lower RLR (lower proportion of root biomass and higher SRL) compared with plants of the population from the subhumid region. Subhumid populations may have greater RMF and shorter roots. Aerts and Chapin III (2000) determined that in species better adapted to a low nutrient supply RGR may decrease because of a lower photosynthetic rate and low nutrient absorption. These species maximize nutrient capture by an increasing low root turnover. When soil water availability dropped to $75 \%$ FC, both populations reached similar roots lengths per unit of total biomass, which in turn led to similar values of gas exchange and also similar RGR. Plants of populations collected in the subhumid region also showed a significant increase in the length of roots per biomass unit, and in the total root biomass under D. The increase in RLR may have contributed to the maintenance of gas exchange and also RGR under water availability restriction. This "root plasticity" seems to be a developed trait of the "subhumid" populations (e.g. population Ro compared to population LP). Plants of the LP population did not show changes in root length per biomass unit (SRL) when soil water availability decreased to $75 \%$ FC or D. Root growth adjustment was mainly related to variations in biomass partitioned to roots. The lower plasticity of LP populations may have influenced gas exchange and, consequently, overall growth. These results are consistent with the observation that individuals having higher RLR due to an increased RMF or higher SRL will in turn increase the capture of soil resources (Eissenstat 1997). We should point out, however, that each population used different strategies to maximize RLR as soil water availability decreased: LP plants increased RMF while maintaining SRL, whereas the Ro plants increased both variables simultaneously.

Taking into account the results obtained here and also those of Bradshaw (1965) and Scheiner (1993), it is important to point out that to determine the plasticity of a given species, it is crucial to include the analysis of morphological and functional traits. These characters together may allow quantification of above- and also below-ground responses to environmental resources variation for a given population. The joint analysis under variable water availability allowed the quantification of 


\begin{tabular}{|c|c|c|c|c|}
\hline Source of variation & $\mathrm{Df}^{\mathrm{z}}$ & $\mathrm{MRS}^{\mathbf{z}}$ & $F$ & $P$ \\
\hline Time & 5 & 111.874 & 9.05 & 0.016 \\
\hline Sorghum halepense population & 6 & 81.032 & 8.53 & 0.021 \\
\hline Soil water availability & 2 & 154.816 & 25.47 & 0.000 \\
\hline Time $\times$ population & 30 & 73.451 & 4.45 & 0.05 \\
\hline Time $\times$ soil water availability & 10 & 74.718 & 5.99 & 0.031 \\
\hline Population $\times$ soil water availability & 12 & 80.332 & 7.14 & 0.027 \\
\hline
\end{tabular}

${ }^{\mathbf{z}} \mathrm{Df}$, degrees of freedom; MRS, mean residuals square. ANOVA Model $r^{2}=0.767$.

the adjustments made by populations already adapted to different environments.

The decrease in soil water availability caused morphological (e.g., root mass fraction) and physiological (e.g., gas exchange) changes in S. halepense. Plants of populations collected from the subhumid region showed small changes in gas exchange compared with those from humid regions (Heschel et al. 2004). Heschel et al. (2004) determined that the magnitude of the plastic responses may vary among the populations of the same species, which may promote both types of adjustments (i.e., morphological and physiological), thus contributing to a reproductive homeostasis. Sexton et al. (2002) also determined that a generalist and a specialist strategy may not be mutually exclusive, as they may occur at different degrees according to the different stages of the crop-weed interaction. This view may be widely applied to increase knowledge on the adaptive changes that weeds could undergo as the agroecosystem suddenly changes, as has recently occurred in the extensive crop production systems of Argentina (Leguizamón, 2003).

Changes in the RGR were closely associated with modifications in the structure of the root system. Different authors have established that root length is closely associated with the absorption surface (Rodrigues et al. 1995). The increased SRL will then increase not only water availability, but also the nutrient uptake from the soil (Eissenstat 1997). Thus, increased SRL in the Ro population may have contributed to increased water uptake and, therefore, a lower soil water potential under D conditions compared with the LP population. This suggestion is supported by the observations of Heschel et al. (2004), who determined that in annuals or perennial (rhizomatous) species, morphological plasticity (an increased biomass or length of roots) is a complementary strategy to the functional strategy (absorption and/or capture of soil water resources). Thus, the higher plasticity (RLR) of plants of the subhumid populations may contribute to sustain higher gas exchange rates at low soil water contents.

In $S$. halepense, gas exchange was maintained under low $\psi_{\mathrm{s}}$ values. This stomatal response is in agreement with the findings of Patterson (1995) and seems to be a general response of many weeds, which supports the view of weeds as "water wasters". The adjustments in biomass and also in root length may have allowed the maintenance of water absorption, gas exchange and growth under low soil water availability. The population from a humid region made a smaller root adjustment, but it still allowed these plants to maintain active gas exchange and growth. Since these findings correspond to two populations from contrasting environments, and taking into account that RGR and gas exchange followed the same pattern, we might extend these conclusions to all the populations from each of both regions (Table 1) although RBR, SRL and RLR were not determined in all populations-sites.

\section{Competitive ability of Sorghum halepense populations and Zea mays}

The analysis of resource complementarity for the different situations indicated that the weed populations and the crop partially competed for resources under non restrictive conditions for growth (FC). Thus, it can be argued that incomplete competition for radiation may have occurred, justifying a RYT value differing from 1 . Satorre and Snaydon (1992) and Aerts (1999) determined that under an adequate water supply, radiation may become the limiting factor. In our experiment, $Z$. mays dominated the competitive process, showing higher aggressivity than the weed populations. The suppressive effect of the crop on the weed varied according to the origin of the weed population. Thus, subhumid populations showed a greater decrease in above-ground biomass than those from humid regions. If there was partial competition for radiation, allocation of increased biomass to the root system might be unfavorable. This behavior was reflected in the lesscompetitive ability of the plants of subhumid populations and it is consistent with the findings of Aerts and Chapin III (2000), who established that a species adapted to limited soil conditions will be dominated by those species adapted to non-restrictive conditions, when grown under non limited conditions. The lower biomass allocation to roots in the populations from humid regions may have reduced the postulated competition for radiation. Although these experiments were not designed to determine the nature (shoot or root) of the competition, based on the absence of resource complementarity we may postulate that competition for water was more important than for any other factor. This behavior is coincident to that studied by Semere and Froud-Williams (2001), who determined that root competition or both root and shoot competition did not produce RYT values statistically different from 1 . As soil water availability decreased, $S$. halepense populations showed a higher competitive ability, maintaining tolerance to competition and increasing their suppressive capacity to the crop. Semere and Froud-Williams (2001) by evaluating the association Pisum sativum/ $Z$. mays, found that under no water restrictions, Z. mays 

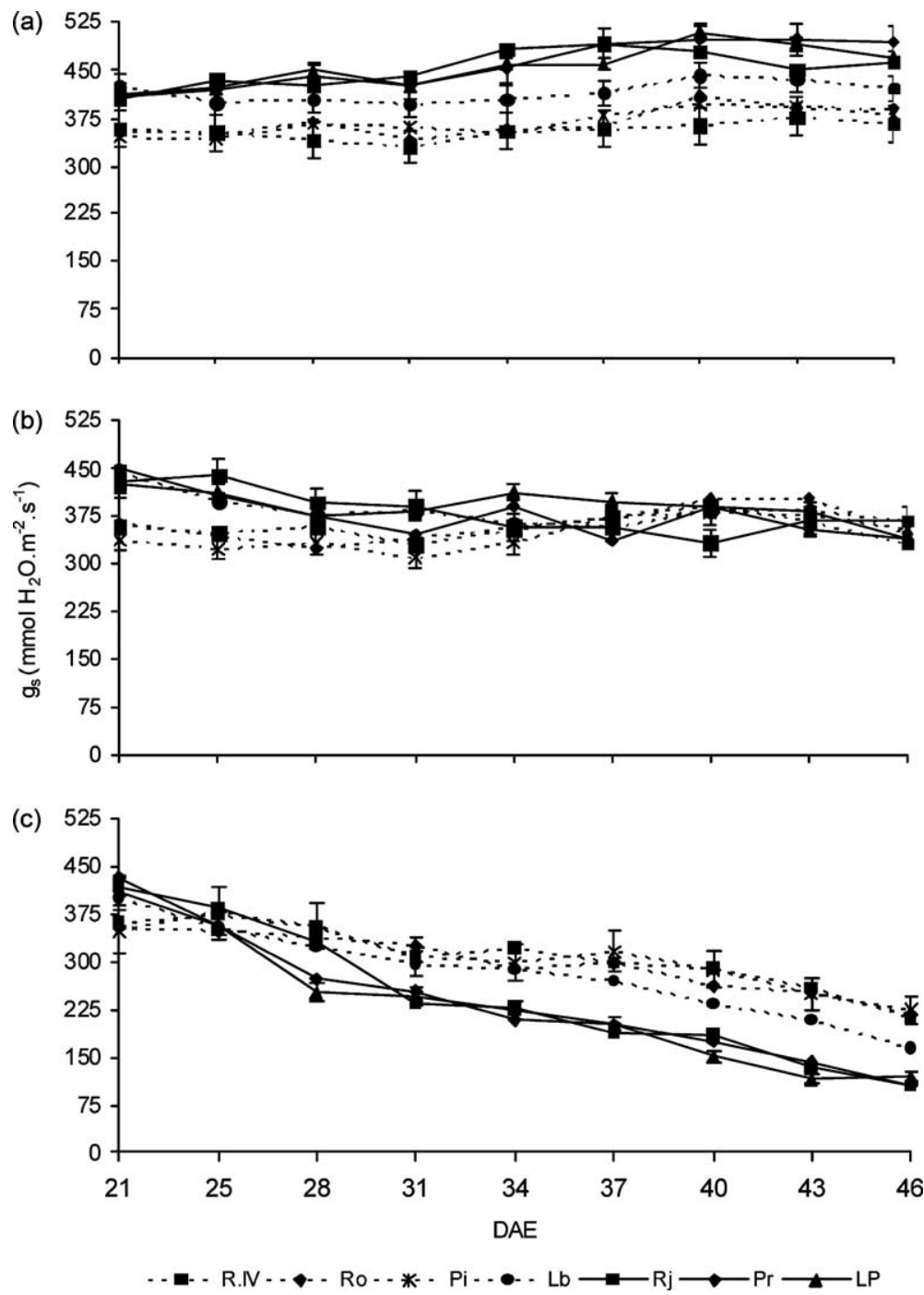

Fig. 5. Time course (days after emergence, DAE) of stomatal conductance $\left(G_{\mathrm{s}}, \mathrm{mmol} \mathrm{H}_{2} \mathrm{O} \mathrm{m}^{-2} \mathrm{~s}^{-1}\right)$ for seven Sorghum halepense populations: Río IV (R.IV), Santa Rosa (Ro), Pico (Pi) and Laboulaye (Lb) from subhumid region and Rojas (Rj), Paraná (Pr) and La Plata (LP) from humid region, grown at three level of water availability: (a) field capacity (FC), (b) $75 \%$ FC and (c) drought (watering withheld). Values were averaged over two growing seasons. Vertical bars indicate standard error $(\mathrm{SE})(n=6)$.

had the highest competitive ability. However, as the soil water availability decreased, Z. mays showed a decreased competitive ability. Semere and Froud-Williams (2001) determined that this behavior was due to the decrease in water uptake in Z. mays under reduced water availability. Similar results were observed here, but the higher aggressivity of the weed populations under decreasing water availability was related to the origin of population. Several studies, which have evaluated the suppressive ability of weeds and the tolerance to competition by different crops (Williams and Boydston 2005) have determined that a positive correlation exists among suppression capacity and tolerance to competition. For Z. mays, this association was only observed under no water restriction (FC), whereas crop suppression ability was lower than that of the weed under water restriction conditions (D). Jannink et al. (2001) determined that suppressive ability may be a very useful trait in the design of integrated management systems, since this attribute may be environmentally independent. Taking into account that the nature of the competition (shoot, root or both) may modify the competitive ability of species under competition (Semere and Froud-Williams 2001; Bonifas et al. 2005) and that many authors have found that root competition may be more intense than shoot competition (Satorre and Snaydon, 1992; Semere and Froud-Williams 2001), it seems necessary to include these factors in the analysis of the constancy of the weed suppressive capacity to environmental variation. 
Table 6. Effects of time, Sorghum halepense population and soil water availability on the transpiratory rate $\left(E, \operatorname{mmol} \mathrm{H}_{2} \mathrm{O} \mathrm{m}^{-2} \mathrm{~s}^{-1}\right)$ of Sorghum halepense

\begin{tabular}{lrrrr}
\hline Source of variation & Df & MRS & \multicolumn{1}{c}{$F$} & $P$ \\
\hline Time & 5 & 11.415 & 9.04 & 0.018 \\
Sorghum halepense population & 6 & 22.454 & 21.58 & 0.001 \\
Soil water availability & 2 & 15.412 & 12.79 & 0.011 \\
Time $\times$ population & 30 & 5.916 & 4.45 & 0.05 \\
Time $\times$ soil water availability & 10 & 8.143 & 6.0 & 0.048 \\
Population $\times$ soil water availability & 12 & 9.954 & 8.63 & 0.021 \\
\hline
\end{tabular}

${ }^{\mathbf{z}} \mathrm{Df}$, degrees of freedom; MRS, mean residuals square. ANOVA Model $r^{2}=0.759$.

In our experiments, under partial competition (FC) the crop had higher aggressivity than S. halepense, whatever the origin of the population. Under water restriction (D), the weed had higher aggressivity, since weed populations increased their suppressive capacity as soil water was increasingly depleted. As the water resource decreased, the suppressive ability of the crop was not modified in the populations adapted to subhumid regions, but populations collected in humid regions had greater suppressive ability. This response is coincident with that reported by Jannink et al. (2001), who stressed the importance of suppressive ability of the crop in the design of more rational weed management systems, as a characteristic to be selected for a genotype to be planted in humid regions, although it should not be a desirable trait if the crop will compete with populations adapted to subhumid regions. Both crop suppressive ability and weed tolerance to competition are variable conditioned, and also depend on the resource for which the competition is established and the location where the weed population has been thriving. This approach is largely absent in the different experiments carried out to evaluate the outcome of the weed-crop competition.

\section{Competitive Hierarchy Among Zea mays and Sorghum halepense under Different Water Supply}

Soil water availability influenced the outcome of competition and the competitive ability in both species. Similarly, McDonald et al. (2004) determined that the patterns of productivity reduction in crops and weeds are deeply influenced by environmental factors and resources. While corn achieved a higher competitive ability under FC, the active gas exchange and maintenance of growth of the above- and below-ground fractions (roots) of the weed under restricted water availability allowed $S$. halepense to out-compete the crop. This response is similar to the findings of other studies showing that morphophysiological traits directly influence the competitive ability of given species, and that the hierarchical competitive ranking is influenced by the environmental conditions (Holt and Orcut 1991; Bonifas et al. 2005).
This seems to be the case of $S$. halepense, a species showing different competitive strategies under different soil water availability. Aggressivity of the populations from humid areas did not increase as water availability decreased, but the populations adapted to subhumid conditions showed an increased aggressivity to corn as water availability decreased. Aggressivity was the result of an increase in the suppressive capacity and sustained tolerance to competition. A possible explanation for this behavior is the increased length of roots in the population from a subhumid origin. Our results are different from those of Novoplansky and Goldberg (2001), who found no change in the competitive hierarchy when water availability decreased in three perennial grasses. This difference may be due to the fact that Novoplansky and Goldberg (2001) did not assess the intensity of competition.

Conversely, our results are consistent with the theory of competition (Booth et al. 2003). This theory predicts that any species allocating more biomass to the root system may achieve a greater competitive ability as soil water availability decreases. The analysis of the competitive processes between $Z$. mays and $S$. halepense must not only involve availability of resources changes, but also the inclusion of different population origins of weeds and crops as a conditioning factor of competition.

\section{CONCLUSIONS}

Populations of $S$. halepense adapted to grow in humid and subhumid regions showed differences in the RGR, root growth and gas exchange. Differences were influenced by the water availability level in the soil. In this way, as soil water availability decreased, there was a larger decrease in RGR and gas exchange in the plants of populations adapted to humid regions, compared with those from subhumid regions.

Both "plant population types" showed differences in their morphological adjustments to water deficit; the physiological adjustments in plants of populations adapted to subhumid regions were of lesser magnitude compared with populations adapted to humid regions. Thus, the increased root length per unit biomass of the plants of populations from the subhumid region may have favored the maintenance of gas exchange and a greater RGR compared with plants of populations adapted to the humid region.

Moreover, the crop had greater competitive ability under non-restrictive resources, whereas the weed populations dominated under high competitive conditions. This response was achieved by maintaining high gas exchange and sustaining a high level of above- and below- ground growth under the period considered.

Sorghum halepense had higher aggressivity as interspecific competition increased. Under restricted soil water availability, the adjustments in above- and below-ground growth and in gas exchange allowed the weed to sustain the competitive hierarchy over the crop. 
(a)
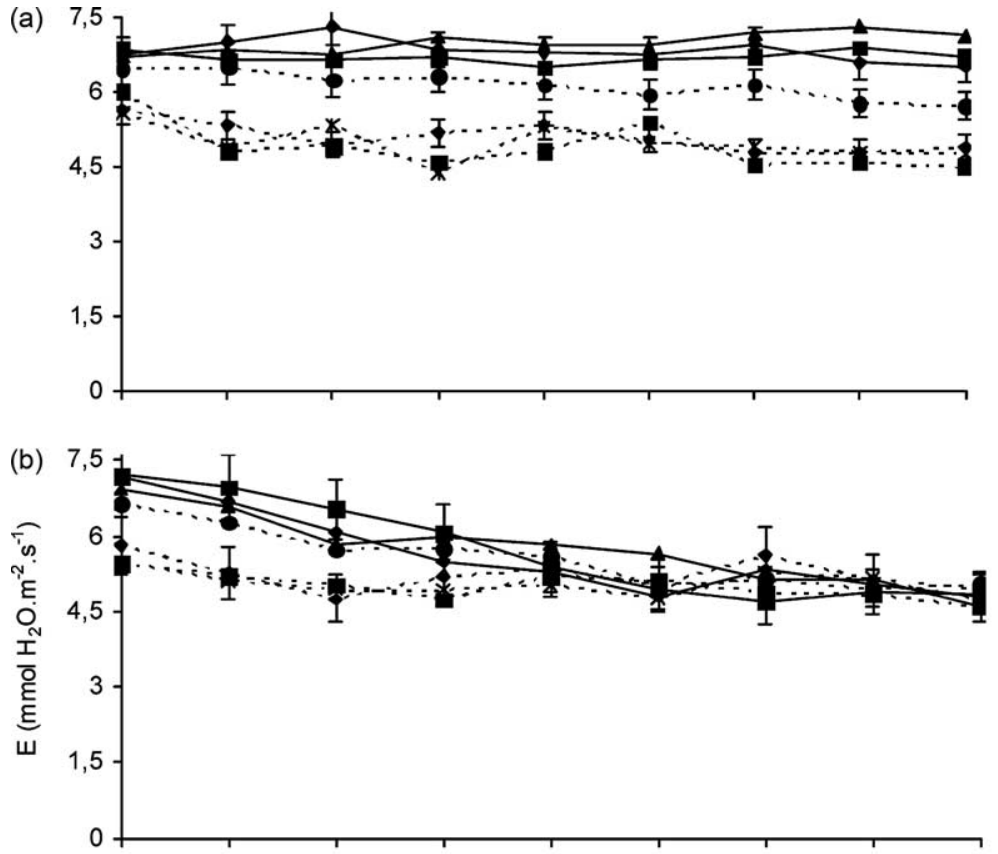

(c)

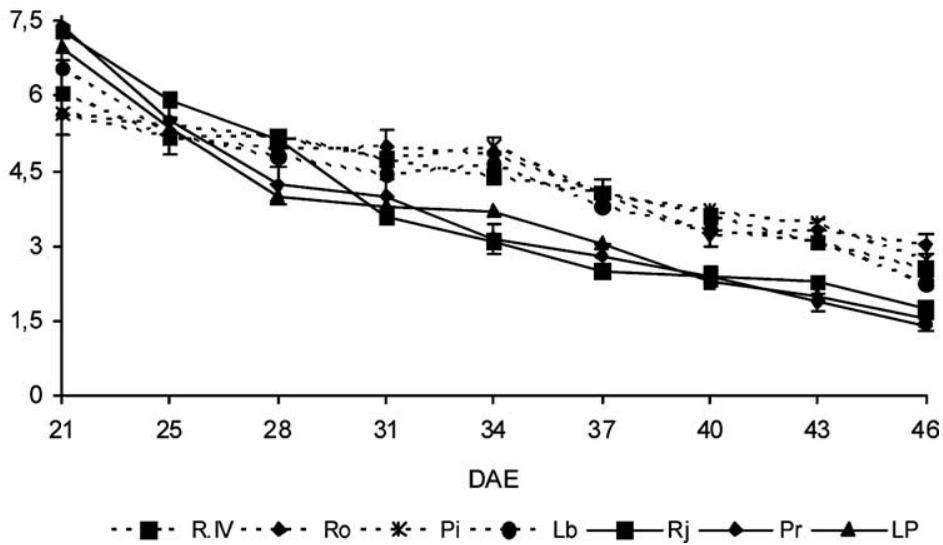

Fig. 6. Time course (days after emergence, DAE) of transpiratory rate $\left(E, \mathrm{mmol} \mathrm{H}_{2} \mathrm{O} \mathrm{m}^{-2} \mathrm{~s}^{-1}\right)$ for seven Sorghum halepense populations: Río IV (R.IV), Santa Rosa (Ro), Pico (Pi) and Laboulaye (Lb) from subhumid region and Rojas (Rj), Paraná (Pr) and La Plata (LP) from humid region, grown at three level of water availability: (a) field capacity (FC), (b) $75 \%$ FC and (c) drought (watering withheld). Values were averaged over two growing seasons. Vertical bars indicate standard error $(\mathrm{SE})(n=6)$.

Table 7. Complementarity of resources (relative yield total, RYT) in Zea mays/Sorghum halepense populations [Río Cuarto (R.IV), Santa Rosa (Ro), Pico (Pi), Laboulaye (Lb), Rojas (Rj), Paraná (Pr) and La Plata (LP)] grown at three levels of water availability: field capacity (FC), 75\% FC and drought (water withheld). Above-ground biomasses measured at Zea mays silking stage

\begin{tabular}{|c|c|c|c|}
\hline & \multicolumn{3}{|c|}{ Relative yield total } \\
\hline & $\mathrm{FC}$ & $75 \% \mathrm{FC}$ & $\mathrm{D}$ \\
\hline $\begin{array}{l}Z . \text { mays }+\mathrm{R} . \mathrm{IV} \\
Z . \text { mays }+\mathrm{Ro} \\
Z . \text { mays }+\mathrm{Pi} \\
Z . \text { mays }+\mathrm{Lb} \\
Z . \text { mays }+\mathrm{Rj} \\
Z . \text { mays }+\mathrm{Pr} \\
Z . \text { mays }+\mathrm{LP} \\
\text { Average }\end{array}$ & $\begin{array}{l}1.40(0.25)^{\mathrm{z}} \\
1.43(0.23) \\
1.41(0.31) \\
1.45(0.29) \\
1.48(0.20) \\
1.53(0.33) \\
1.52(0.15) \\
1.46(0.27)\end{array}$ & $\begin{array}{l}1.10(0.15) \\
1.11(0.18) \\
1.13(0.14) \\
1.10(0.14) \\
1.03(0.09 \\
1.03(0.10) \\
1.02(0.08) \\
1.07(0.09)\end{array}$ & $\begin{array}{l}0.92(0.14) \\
0.87(0.12) \\
0.90(0.11) \\
1.02(0.12) \\
0.91(0.10) \\
0.90(0.15) \\
0.91(0.10) \\
0.92(0.09)\end{array}$ \\
\hline
\end{tabular}

${ }^{\mathrm{z}}$ Values in parentheses are standard errors of the mean. Values were averaged over two growing seasons $(n=3)$. 

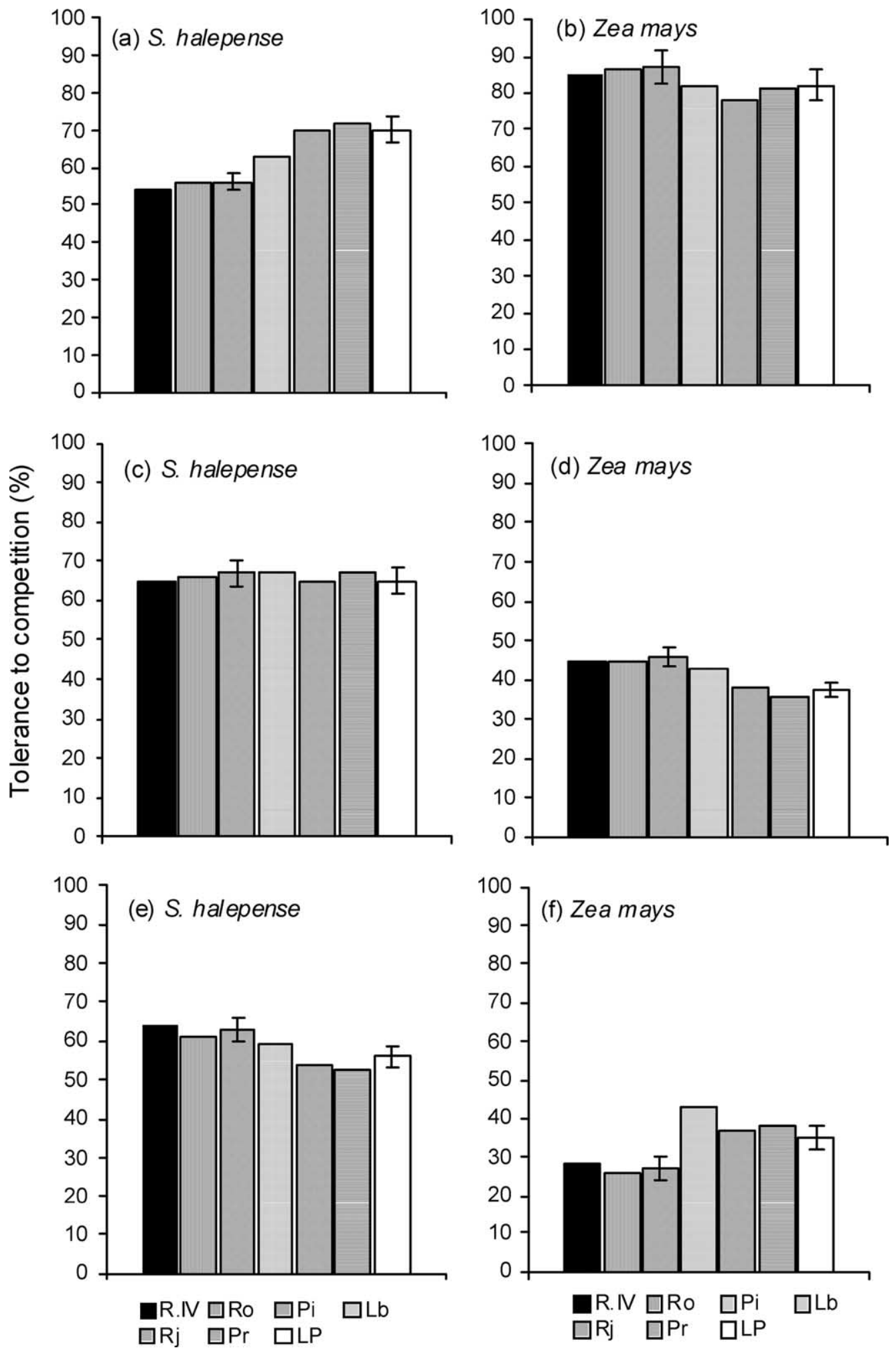

Fig. 7. Tolerance to competition (percent above-ground biomass at flowering stage in both species) of Sorghum halepense and Zea mays grown at three level of water availability: (a, b) field capacity; (c, d) 75\% field capacity and (e, f) drought (watering withheld). Sorghum halepense populations: Río IV (R.IV), Santa Rosa (Ro), Pico (Pi) and Laboulaye (Lb) from subhumid region and Rojas $(\mathrm{Rj})$, Paraná (Pr) and La Plata (LP) from humid region. Zea mays: hybrid AX 840. Values were averaged over two growing seasons. Vertical bars indicate standard error (SE) $(n=3)$. 

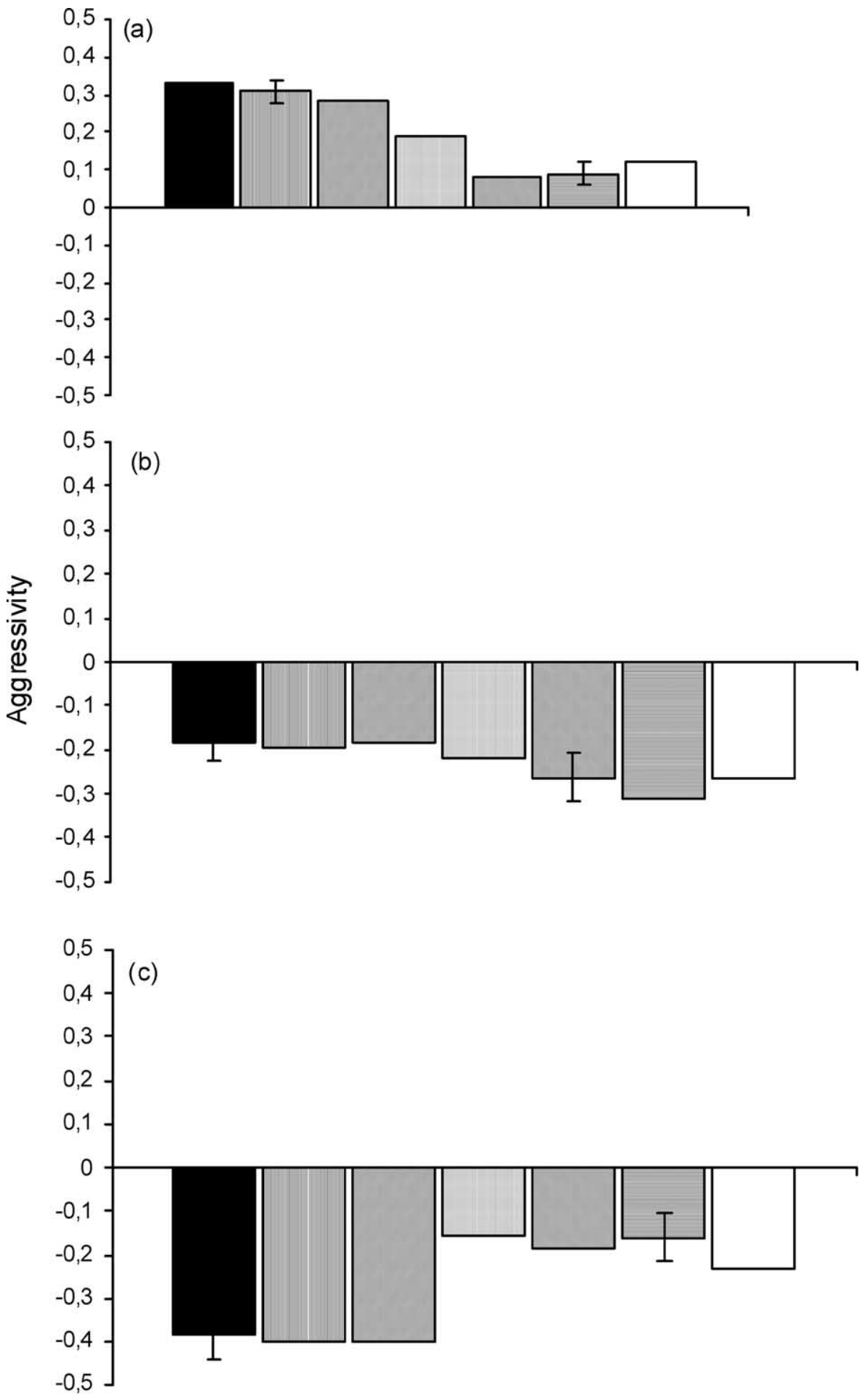

aR.IV $\quad \square R o \quad \square P i \quad \square L b \quad \square R j \quad \square P r \quad \square L P$

Fig. 8. Competitive ability (Aggressivity) of Zea mays in competition with seven Sorghum halepense populations grown at three level of water availability: (a) field capacity, (b) 75\% field capacity and (c) drought (watering withheld). Sorghum halepense populations: Río IV (R.IV), Santa Rosa (Ro), Pico (Pi) and Laboulaye (Lb) from subhumid region and Rojas (Rj), Paraná (Pr) and La Plata (LP) from humid region. Zea mays: hybrid AX 840. Values were averaged over two growing seasons. Vertical bars indicate standard error (SE) $(n=3)$. 
Acciaresi, H. A. and Guiamet, J. J. 2010. Below- and aboveground growth and biomass allocation in Zea mays and Sorghum halepense in response to soil water competition. Weed Res. 50: 481-492.

Aerts, R. 1999. Interspecific competition in natural plant communities: mechanisms, trade-offs and plant-soil feedbacks. J. Exp. Bot. 50: 29-37.

Aerts, R. and Chapin, F. S. III. 2000. The mineral nutrition of wild plants revisited: A re-evaluation of processes and patterns. Adv. Econ. Res. 30: 1-67.

Bonifas, K. D., Walters, D. T, Cassman, K. G. and Lindquist J. L. 2005. Nitrogen supply affects root:shoot ratio in corn and velvetleaf (Abutilon theophrasti). Weed Sci. 53: 670-675.

Booth, B. D., Murphy, S. D. and Swanton, C. J. 2003. Interaction between population. I: competition and allelopathy. Pages 119-139 in B. D. Booth, S. D. Murphy, and C. J. Swanton, eds. Weed ecology in natural and agricultural systems. CABI Publishing, Oxford, UK.

Bradshaw, A. D. 1965. Evolutionary significance of phenotypic plasticity in plants. Adv. Genet. 13: 115-155.

Burt, G. W. 1974. Adaptation of Johnson grass. Weed Sci. 22: 59-63.

de Wit, C. T. and Van Den Berg, J. P. 1965. Competition between herbage plants. Neth. J. Agric. Sci. 13: 212-221.

Eissenstat, D. M. 1997. Trade-offs in root form and function. Pages 173-199 in L. E. Jackson, ed. Ecology in agriculture. Academic Press, San Diego, CA.

Ghosheh, H. Z., Holshouser, D. L. and Chandler, J. M. 1996. The critical periods of johnsongrass (Sorghum halepense) control in field corn (Zea mays). Weed Sci. 44: 944-947.

Goldberg, D. E. and Landa, K. 1990. Competitive effect and response: hierarchies and correlated traits in the early stages of competition. J. Ecol. 79: 1013-1030.

Grime, J. P. and Mackey, J. M. L. 2002. The role of plasticity in resource capture by plants. Evol. Ecol. Res. 16: 299-307.

Heschel, M. S., Sultan, S. E., Glover, S. and Sloan, D. 2004. Population differentiation and plastic responses to drought stress in the generalist annual, Polygonum persicaria. Int. J. Plant Sci. 165: 817-824.

Holt, J. S. 1988. Ecological and physiological characteristics of weeds. Pages 7-23 in M. A. Altieri and M. Liebman, eds. Weed management in agroecosystems: Ecological approaches. CRC Press, Boca Raton, FL.

Holt, J. S. and Orcut, D. R. 1991. Functional relationships of growth and competitiveness in perennial weeds and cotton (Gossypium hirsutum). Weed Sci. 39: 575-584.

Jannink, J. L., Jordan, N. R. and Orf, J. H. 2001. Feasibility of selection for high weed suppressive ability in soybean: absence of tradeoffs between rapid initial growth and sustained later growth. Euphytica 120: 291-300.

Leguizamón, E. S. 2003. Biología poblacional de Sorgo de Alepo (Sorghum halepense L. Pers). Estrategias complementar- ias y efectos del sistema de manejo. Ph.D. thesis. Faculty of Agricultural Sciences, Rosario National University, Rosario, Argentina. $135 \mathrm{pp}$.

Lindquist, J. L. 2001. Mechanisms of crop loss due to weed competition. Pages 233-253 in R. K. D. Peterson and L. G. Higley, eds. Biotic stress and yield loss. CRC Press, Boca Raton, FL.

Malone, C. R. 1967. A rapid method for enumeration of viable seeds in the soil. Weed Sci. 15: 381-382.

McDonald, A. J., Riha, S. J. and Mohler, C. L. 2004. Mining the record:historical evidence for climatic influences on Zea mays - Abutilon theophrasti competition. Weed Res. 44: 439445.

McWhorter, C. G. and Jordan, T. N. 1976. Comparative morphological development of six johnsongrass populations. Weed Sci. 24: 270-275.

Novoplansky, A. and Goldberg, D. 2001. Effects of water pulsing on individual performance and competitive hierarchies in plants. J. Veg. Sci. 12: 199-208.

Patterson, D. T. 1995. Effects of environmental stress on weed/ crop interactions. Weed Sci. 43: 483-490.

Poorter, H. 1989. Plant growth analysis: towards a synthesis of the classical and the functional approach. Physiol. Plant. 75: 237-244.

Rodrigues, M. L., Pacheco, C. M. A. and Chaves, M. M. 1995. Soil-plant water relations, root distribution and biomass partitioning in Lupinus albus L. under drought conditions. J. Exp. Bot. 46: 947-956.

Satorre, E. H. and Snaydon, R. W. 1992. A comparison of root and shoot competition between spring cereals and Avena fatua L. Weed Res. 32: 45-55.

Scheiner, S. M. 1993. Genetics and evolution of phenotypic plasticity. Ann. Rev. Ecol. Syst. 24: 35-68.

Semchenko, M. and Zobel, K. 2005. The effect of breeding on allometry and phenotypic plasticity in four varieties of oat (Avena sativa L.). Field Crops Res. 93: 151-168.

Semere, T. and Froud-Williams, R. J. 2001. The effect of pea cultivar and water stress on root and shoot competition between vegetative plants of Zea mays and pea. J. Appl. Ecol. 38: 137-145.

Sexton, J. P., McKay, J. K. and Sala, A. 2002. Plasticity and genetic diversity may allow saltcedar to invade cold climates in North America. Ecol. Appl. 12: 1652-1660.

Sultan, S. E. 2000. Phenotypic plasticity for plant development, function, and life-history. Trends Plant Sci. 5: 537-542. Wiese, A. F. and Vandiver, C. W. 1970. Soil moisture effects on competitive ability of weeds. Weed Sci. 18: 518-519.

Williams, M. M. and Boydston, R. A. 2005. Tolerance of three sweet corn hybrids to wild proso millet interference. Proc. WSSA Meeting 45: 83. 